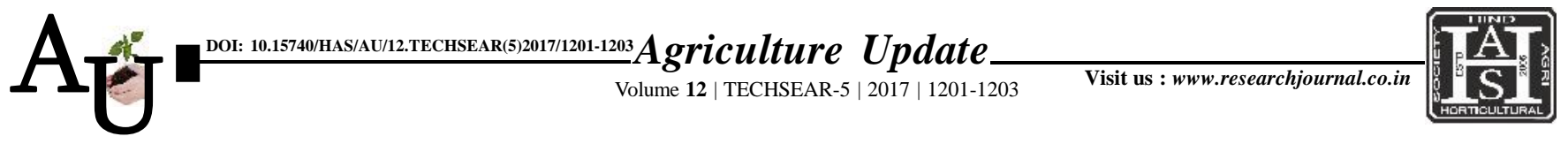

\title{
Research Article: Optimization of production factors in Rabi grain sorghum under resource constraints
}

\author{
S.P. KAUSALYE, R.L. AUNDHEKAR, S.S. SOLUNKE AND H.V. KALPANDE
}

Article Chronicle:

Received :

15.07.2017;

Accepted :

30.07.2017

KEY WoRDS:

Full package of practices, Priority inputs, Sorghum, GMR, NMR

Author for correspondence :

\section{S.P. KAUSALYE}

Sorghum Research Station (V.N.M.K.V.), PARBHANI (M.S.) INDIA Email : dr.kausale@ gmail.com

See end of the article for authors' affiliations
SUMMARY : A field experiment was conducted during Kharif season 2016-17 at Sorghum Research Station, V.N.M.K.V., Parbhani . The objective of the experiment was to find out per cent loss of yield when one of the Priority inputs miss due to whatever reasons then know how much per cent reduction in yield found. The results clearly indicated that test weight, grain yield, fodder yield $\mathrm{kg} \mathrm{ha}^{-1}$, harvest index (\%), GMR, NMR Rsha ${ }^{-1}$ and B:C ratio were significantly influenced by application of all priority inputs. Treatment $\mathrm{T}_{2}$ Full package of practices (FPP) to Rabi sorghum recorded highest test weight, panicles $/ \mathrm{m}^{-2}$, grain yield, fodder yield $\mathrm{kg} \mathrm{ha}^{-1}$, harvest index (\%), GMR, NMR Rs.ha ${ }^{-1}$ and B:C ratio and was found significantly superior over rest of the all treatments, however it was found at par with treatment $\mathrm{T}_{7}$ FPP minus seed treatment with PSB and Azospirillum. Among different Rabi sorghum priority inputs adaptation of only improved variety without any input treatments recorded significantly lowest test weight, grain yield, fodder yield $\mathrm{kg} \mathrm{ha}^{-1}$, harvest index (\%), GMR, NMR Rs.ha ${ }^{-1}$ and B : C ratio over all priority inputs treatments.

How to cite this article : Kausalye, S.P., Aundhekar, R.L., Solunke, S.S. and Kalpande, H.V. (2017). Optimization of production factors in Rabi grain sorghum under resource constraints. Agric. Update, 12(TECHSEAR-5) : 1201-1203; DOI: 10.15740/HAS/AU/12.TECHSEAR(5)2017/1201-1203. 